\title{
To sider av same slag. Utstillingsanalyse av musea på Ncome Blood River Battle Site
}

LINE GRøNSTAD*

Title: Two sides of the same battle - an analysis of the exhibitions at the Ncome Blood River battle site.

Abstract: In 1838, Afrikaners won a battle against a Zulu army far superior in numbers. In the 1990s, two museums were set up at the site of this battle. The Blood River Museum celebrates the Afrikaners' victory, while Ncome Museum marks the heroism of the Zulus. The article deals with how these museums are using the same historical event in two different ways. After 1994, the anniversary of the battle (16 December) was designated Day of Reconciliation. Yet there is little reconciliation visible in the exhibitions. Zulus and Afrikaners are portrayed as diametrical opposites, while the internal conflicts among the Zulu and among the Afrikaners are ignored. Dichotomisation and exclusion thus occupy a clearer place in these exhibitions than any message of reconciliation.

Key words: South Africa, exhibition analysis, Ncome, Blood River, Zulu, Afrikaner.

\section{INTRODUKSJON}

“Eg ønskjer ikkje å ta deg med til Ncome Museum på den andre sidan av elva .” Det er oktober 2004, og eg besøker staden for slaget ved Ncome Blood River, i provinsen KwaZuluNatal, Sør Afrika, for fyrste gong. Omvisaren min, ein kvit afrikandisk mann i femtiåra, har allereie teke meg til Blood River Museum. "Eg var på Ncome Museum då det var nytt i 1999, og informasjonen der er ikkje korrekt. Du forstår, eg trur på fakta, slike eg finn i bøker," held han fram.
Slik gjorde han meg nysgjerrig. Kva slags fakta blir framstilt på Ncome Museum, og kva slags fakta blir framstilt på Blood River $\mathrm{Mu}-$ seum? Og ikkje minst, kvifor er det to museum der i staden for eitt? Musea ligg berre nokre få hundre meter frå kvarandre i luftline, men ein må kjøre tre kilometer fordi elva mellom musea manglar bru. I denne artikkelen vil eg sjå på korleis slaget ved Ncome Blood River mellom 12000 zuluar og 700 på afrikandisk side den 16. desember 1838, blir framstilt i dei to musea som vart reist på staden for slaget på 1990-talet. Gjennom fyrst å sjå kort på den 
historiske bakgrunnen for slaget og opprettinga av musea, og etterpå gjennom analyse av utstillingane i dei to musea vil eg skissere nokre svar på desse spørsmåla.

Materialet for analysen er fram for alt fleire besøk til dei to musea frå oktober til desember 2008, intervju med Nhlanhla Mkhulisi, dagleg leiar på Ncome Museum, Dawie Viljoen, dagleg leiar på Blood River Museum, og Cecilia Kruger, som laga utstillinga til Blood River Museum. I tillegg har eg nytta historikarar som tek for seg hendingane rundt slaget, som John Laband (1995; 2009) og Hermann Giliomee (2003), og andre forskarar som har sett nærare på bygginga av dei to musea ved Ncome Blood River, som Nsizwa Dlamini (2001), Sabine Marschall (2008) og Paula Girshick (2004). I analysen er hovudvekta lagt på val av forteljinger, omgrep og formuleringar som blir framstilt som sjølvsagte i dei to utstillingane. Særskilt er det lagt vekt på omgrep som ikkje er konsekvente, og der ulike namn er brukt på det same og same namn på fleire fenomen. Dette er såleis ein diskursanalyse (Jørgensen \& Phillips, 1999) der nokre tema i det sørafrikanske samfunn kjem til synes gjennom utstillingane og gjennom eksistensen av to museum om same slag på same stad.

\section{HISTORISK BAKGRUNN FOR SLAGET OG MUSEA}

På byrjinga av 1800-talet vart mange av folkegruppene i regionen KwaZulu-Natal samla til det som i dag blir kalla zuluar, leia av kong Shaka Zulu. På same tid migrerte mange afrikandarar austover frå Cape Town-distriktet i det som seinare vart kalla Det store trekket. Afrikandarane er hovudsakleg av nederlandsk opphav. I 1837, året før slaget det her er tale om, tok dei fyrste afrikandarane kontakt med
Dingane, som då var konge i regionen, med spørsmål om å få ein del av landområda hans. Ei gruppe afrikandarar besøkte han same år. Her vart det signert ein avtale som skildra arealet som afrikandarane skulle fà. Siste dagen av besøket arrangerte zuluane ein fest som avslutta med at alle afrikandarane vart drepne.

Fleire slag følgde der zuluane vann. I november 1838 gjekk ein afrikandisk hær på 700 menn og 64 oksevogner fulle med våpen og ammunisjon i retning Dingane sin hær. Erfaringar frå tidlegare slag mot zuluar og xhosafolk hadde vist at den beste måten å vinne for afrikandarane var å velje stad med omhug og plassere oksevognene i ein stor halvsirkel, slik at dei kunne fungerte som eit fort. Eit løfte vart gjenteke dagleg blant afrikandarane i hæren der dei lova Gud å bygge ei kyrkje og halde dagen heilag dersom han gav dei siger over zuluane. Då dei to hærane oppdaga kvarandre, stilte afrikandarhæren seg opp i sirkelformasjon med vognene sine på ein eigna plass ved elva Ncome. Om morgonen 16. desember angreip zulusoldatane. Mellom 3000 og 3500 zuluar vart skotne i løpet av morgonen, og elva fekk etterpå namnet Blood River. Etter slaget drog hæren til den no frårømde hovudstaden. Her skal dei ha funne den signerte avtalen om overføring av land. Mange har stilt spørjeteikn ved om avtalen er ekte, og i så fall gyldig (Laband, 1995: 103). Slik tvil blir sett vekk frå i det ein kan kalle ein "afrikandisk versjon av hendinga" (Mills og Williams, 2006: 32).

I dag er det lagt stor vekt på løftet, ofte kalla "covenant" eller pakt, som afrikandarane gav i forkant av slaget, i gjenforteljinga av slaget ved Ncome Blood River. Men dagen vart ikkje markert i særleg grad før mot slutten av 1800-talet (Giliomee, 2003: 166). Som symbol vart det då nytta for å vise at ved hjelp av 
LINE GRøNSTAD

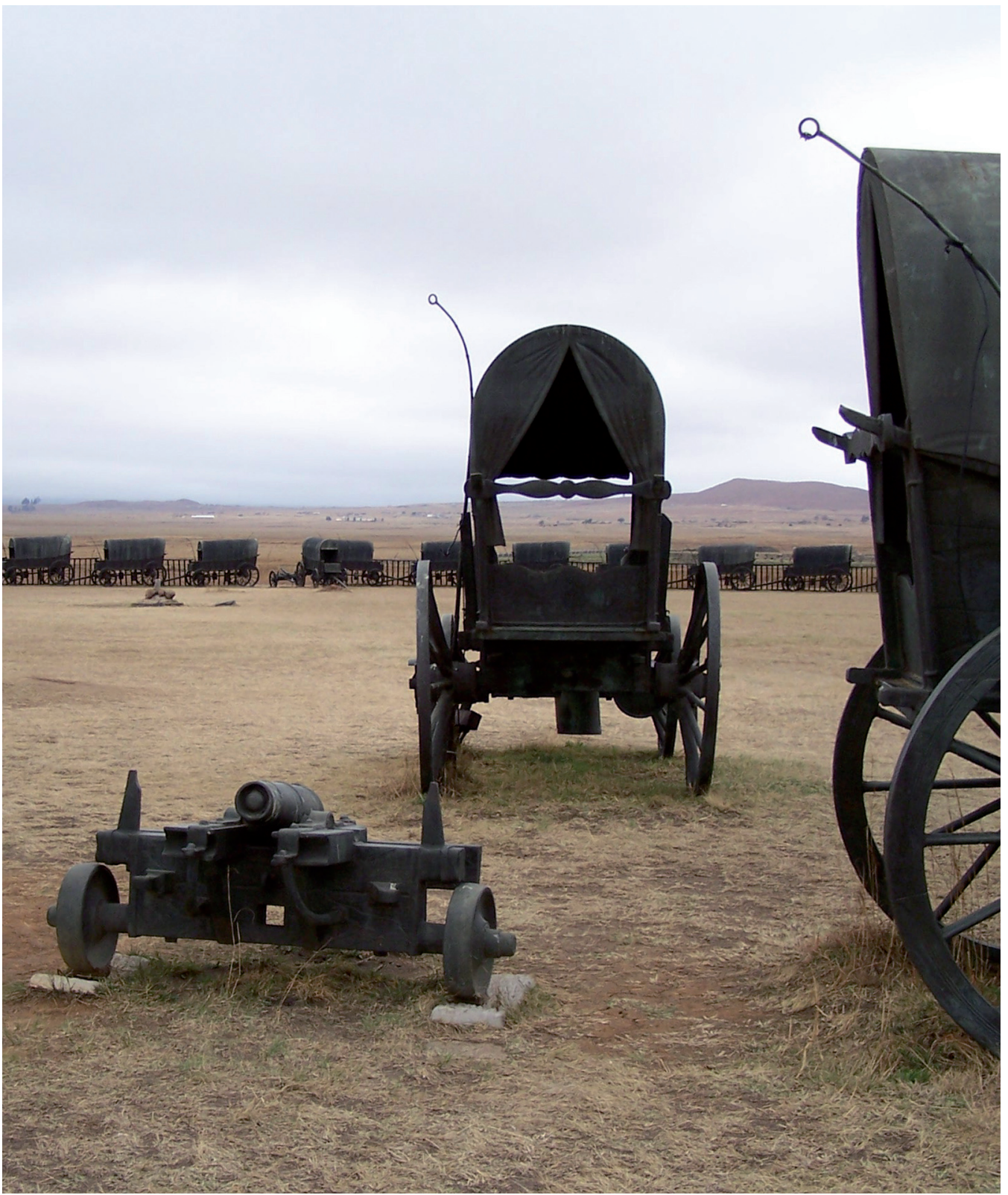

Fig. 1. Slik skal oksevognene til afrikandarane ha stått under slaget. Monumentet vart sett opp på 1970-talet og er omtrent 400 meter i omkrins. Foto: Line Gronstad. 
To sider aV same slag. Utstillingsanalyse aV musea pA Ncome Blood River Battle Site

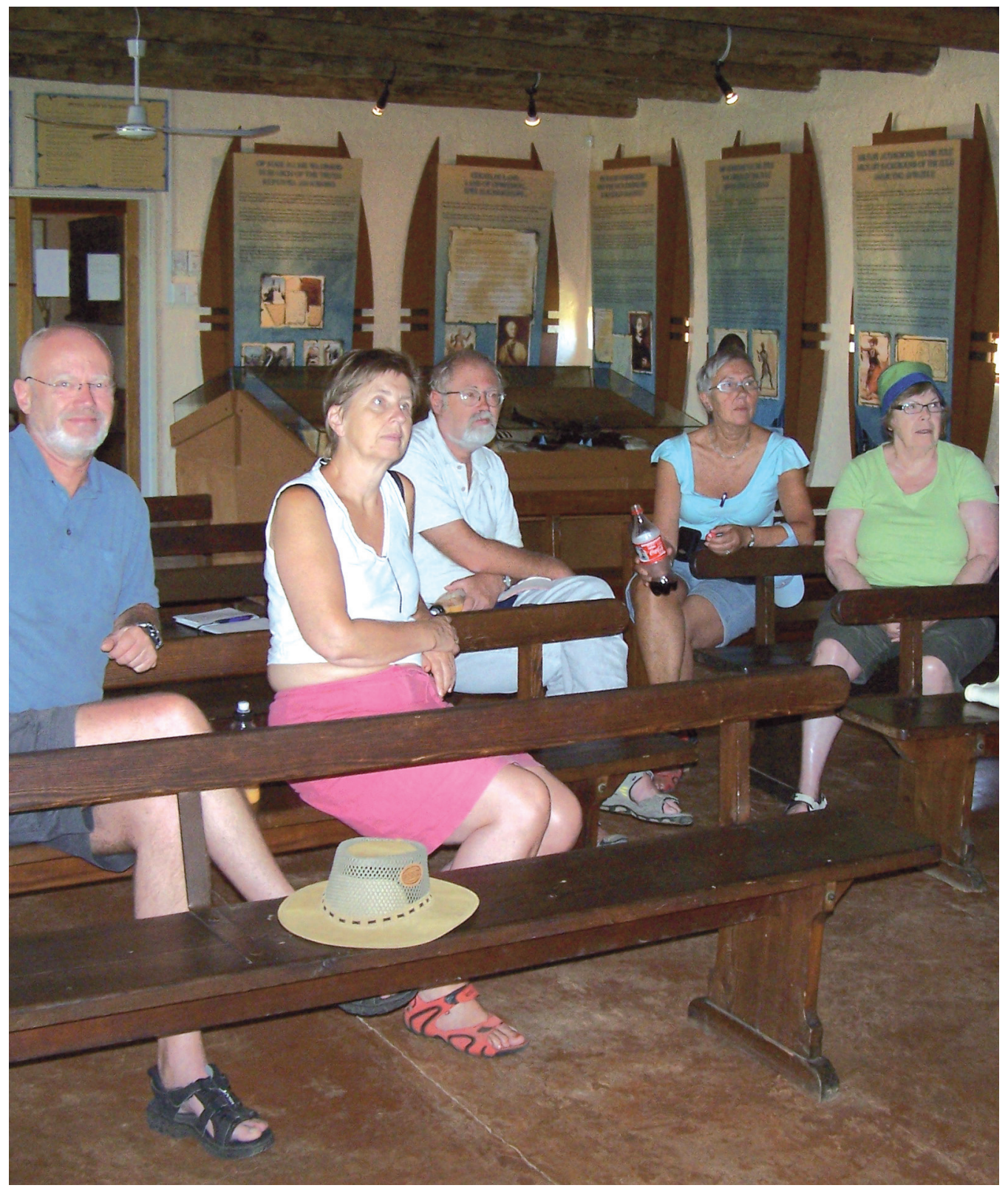

Fig. 2. Besøkande ser framstillinga av slaget på ein tv-skjerm bak fotografen. Foto: Line Gronstad. 
Gud kunne afrikandarane, lik israelittane i det gamle testamentet, vinne mot dårlege odds, i eit landskap av fiendar som inkluderte mellom anna zuluar (Ehlers, 2003). Alt som ikkje passa inn i ein slik nasjonalistisk diskurs vart ignorert (du Toit, 1980: 114; du Toit \& Giliomee, 1983: xv). Løftet heng i dag som hustavle i mange afrikandiske heimar, og det er dette løftet som på mange vis har gjort det mogleg å transformere slaget til ei unik hending i afrikandarane si historie (van Jaarsveld, 2008).

Årsdagen for slaget vart offisiell fridag for heile Sør Afrika i 1910. Både 100-årsdagen i 1938, 150-årsdagen i 1988, og 170-årsdagen i 2008, vart feira med gammaldagse klede og opptog med oksevogner av typen som vart nytta under slaget. Slik kom mange afrikandarar i kontakt med si eiga mytologiske fortid (Giliomee, 2003: 433). Staden for slaget vart i enda større grad gjort til symbol gjennom at ei granittstatue forma som ei oksevogn vart påbyrja i 1938, og eit anna monument i bronse, forma som sirkelformasjonen frå 1838 i naturleg storleik, vart sett opp i 1971. Men det var ikkje berre afrikandarar som brukte slaget som symbol. Historikaren Jabulani Sithole meiner at ANC såg slaget som ei legitimering av væpna kamp mot det undertrykkande regimet. På same dato, 16. desember, i 1961 vart difor militærvingen av ANC lansert (1998: 34).

I 1994, då Sør Afrika vart demokratisk, vart dagen døypt til Forsoningsdagen, og eit nytt innhald vart forsøkt gitt dagen, heller enn å avskrive han.

For mange afrikandarar er ikkje 16. desember ein dag for forsoning, men ein dag for å minnast ei periode som har forma den politiske og historiske ideologien til det afrikandiske folket medan dei kjende seg truga av både svarte og kvite i sitt eige land. Denne kjensla av usikkerheit kan sjåast igjen i Sør Afrika etter 1994 (Visser, 2004). Det har blitt hevda at afrikandisk nasjonalisme ikkje lenger finst (Blaser, 2004: 192), men den stadig aukande mengda afrikandarar som årleg samlar seg på staden for slaget på 16. desember tilseier at det ikkje stemmer. Då Ncome Museum vart opna 16. desember 1998 var det rundt 15000 besøkande (Dlamini, 2001: 133). Men på andre sidan av elva var ein annan seremoni, som vanleg på årsdagen for slaget, og få afrikandarar kom over til Ncome Museum.

\section{Musea}

Blood River Museum viser seg som ein låg mursteinsbygning bak ein stor, open port og er omkransa av eit høgt gjerde. Granittmonumentet forma som ei oksevogn frå 1938 er plassert utanfor museumsbygget, og bronsemonumentet frå 1971 er nokre hundre meter lengre nede i retning elva og Ncome Museum.

Museet vart bygd i 1996, og vart fram til 2002 styrt av ein afrikandisk kulturorganisasjon kalla Foundation for the Blood River Covenant Site. Sidan har staden vore styrt av Voortrekkermonumentet i Pretoria. Dagens utstilling vart laga av Cecilia Kruger og Estelle Pretorius frå Voortrekkermonumentet same året. Innanfor hovudinngangen er ein museumsbutikk, til høgre ein koseleg kafé, og til venstre utstillinga. Utstillingsrommet er romsleg, firkanta og litt lengre enn det er breidt. I motsatt ende av inngangen heng ein TV som viser ein film om hendingar før, under og etter slaget, og supplerar utstillinga som tek for seg dei same hendingane. Fleire trebenkar er plassert i retning TVen. På veggane heng tjue panel forma som zuluskjold, avlange med sider som møtast i ein spiss oppe og nede. Midt på golvet, bak benkane og nærast inngangen, står to 
glasmontrar med replika av klede og våpen for afrikandarane i den eine og zuluane i den andre. Lyden frå filmen og den teatralske musikken føl besøkaren rundt i lokalet.

Ncome Museum var eit av fleire prosjekt sett i gang av Department of Arts, Culture, Science and Technology (DACST) for å rette opp skeivheita $\mathrm{i}$ framstillinga av hendingar og folk i Sør Afrika utan å fjerne monument og museum som framstilte "kvit" historie (Girshick, 2008: 38). Til å byrje med var museet tenkt som eit tillegg til Blood River $\mathrm{Mu}$ seum i form av eit minnesmerke om zuluane si oppleving av slaget, men dette vart ikkje teke godt i mot av konservative afrikandarar. Snart vart området på motsatt side av elva staden for museet. Hærformasjonen zuluane nytta vart brukt som utgangspunkt for forma på det brunrosa hovudbygget. På sida som vender mot bronsemonumentet og Blood River Museum vart det mala på skjold som representerer dei ulike zuluregimenta. Bygget vart opna 16. desember 1998, og utstillingar i november 1999. I tillegg er fleire hytter plassert på området, der ein fungerer som museumsbutikk. Utviklinga av utstillinga frå 2008 er gjort av Dalifa Ngobese frå Ncome Museum.

Inne i museumsbygget er golvet forma som eit langt, smalt skjold, spiss i kvar ende og breiast i midten. Utstillinga har namnet "Ncome: Another point of view". Langs dei to sidene er utstillinga, atten panel med gjenstandar, tekst, illustrasjonar og foto. I enden av rommet står ein TV der ein film viser markeringa av Forsoningsdagen på staden med musikk og dansekonkurransar. Trommer og heiing følgjer besøkaren i utstillinga. To dokker, ei kvinne og ein mann i naturlege storleikar, kledd i tradisjonelle klede, står ved inngangen. Her er utstillinga plassert langs dei to bua veggane som møtast i kvar ende, der det også er inngangsdører.

Panela på Blood River Museum fortel historia om slaget, og er plassert kronologisk i klokkeretning på veggane rundt rommet. På Ncome Museum er forskjellige tema vist ved hjelp av tekst, foto, teikningar og gjenstandar, der nokre handlar om slaget og andre om zulukultur. Panela tek form av både plansjar og montrar og det er ikkje brukt kronologi som presentasjonsform.

\section{EIN KONGE OG EI FELLES REISE}

Utstillinga i Blood River Museum byrjar med å fortelje korleis det hadde seg at afrikandarane var i denne regionen. I 1652, får vi vite, kom dei fyrste europeiske fastbuande til Sør Afrika. Viktigare i denne samanheng er likevel Det store trekket, som vara mellom 1835 og 1838. Afrikandarane som deltok i trekket blir skildra som "hardened, self-sufficient, highly independent people. They were bound together by their aspirations to self-government and freedom, a communal language, which [were] later to become Afrikaans, and their strong Calvinist religion." Som gruppe har dei ei rekke sams eigenskaper. Som sanningsvitne er eit brev, skrive av den britiske guvernøren Sir Benjamin D’urban i 1837, sitert i panelet:

It is very sad that those farmers who have left the Colony, belonged for the most part, to the oldest and most notable inhabitants of the districts from whence they came and that the departure of these brave, patient, hard working, God fearing people will be a loss of untold proportions for the Colony... The most valuable part of our rural population is therefore irretrievably lost.

Den europeiske bakgrunnen til afrikandarane 


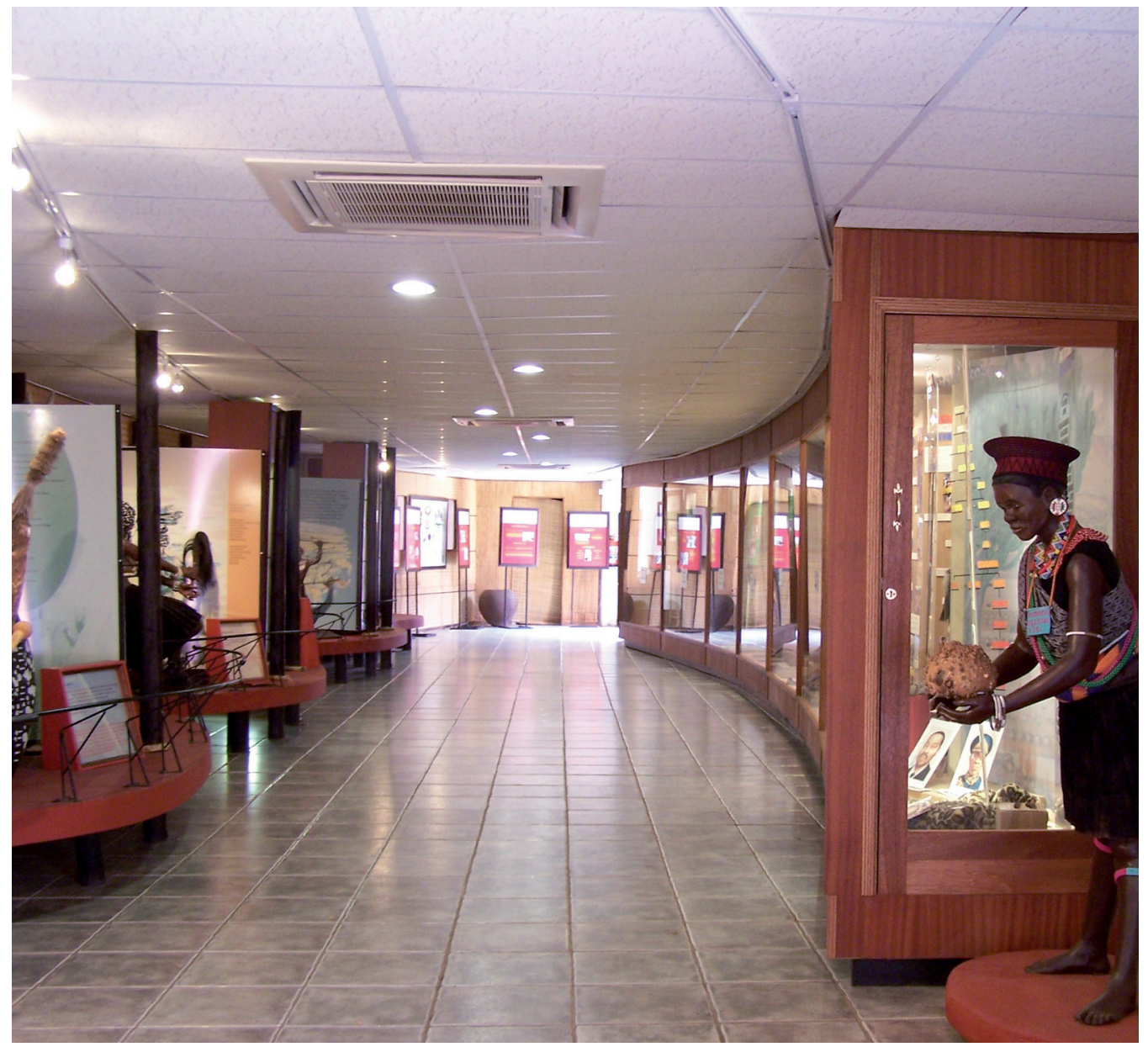

Fig. 3. Utstillinga på Ncome Museum. Veggane er bua og gjer at golvet fär form som eit zuluskjold. Foto: Line Grønstad.

blir fokusert på, og at det opp gjennom åra har komme "farga" blod inn blir ignorert (Coetzee, 1998). "It is estimated that a minimum of 15 000 white people took part in the trek, accompanied by about 5000 servants," står det i utstillinga. Ein fjerdedel av deltakarane på trekket var svarte eller farga, men i forteljinga om trek- ket er alle trekkarane kvite. Dei "andre" er tenarar, og rollene dei spela i trekket er sjeldan inkludert i forskinga gjort på trekket (Bredekamp, 13.10.2006; Gilje, 2007). Denne kritikken kan såleis rettast til museet også.

Ncome Museum si utstilling byrjar med å fortelje om den noverande kongen av zuluane, 
To sider aV same slag. Utstillingsanalyse aV musea pA Ncome Blood River Battle Site

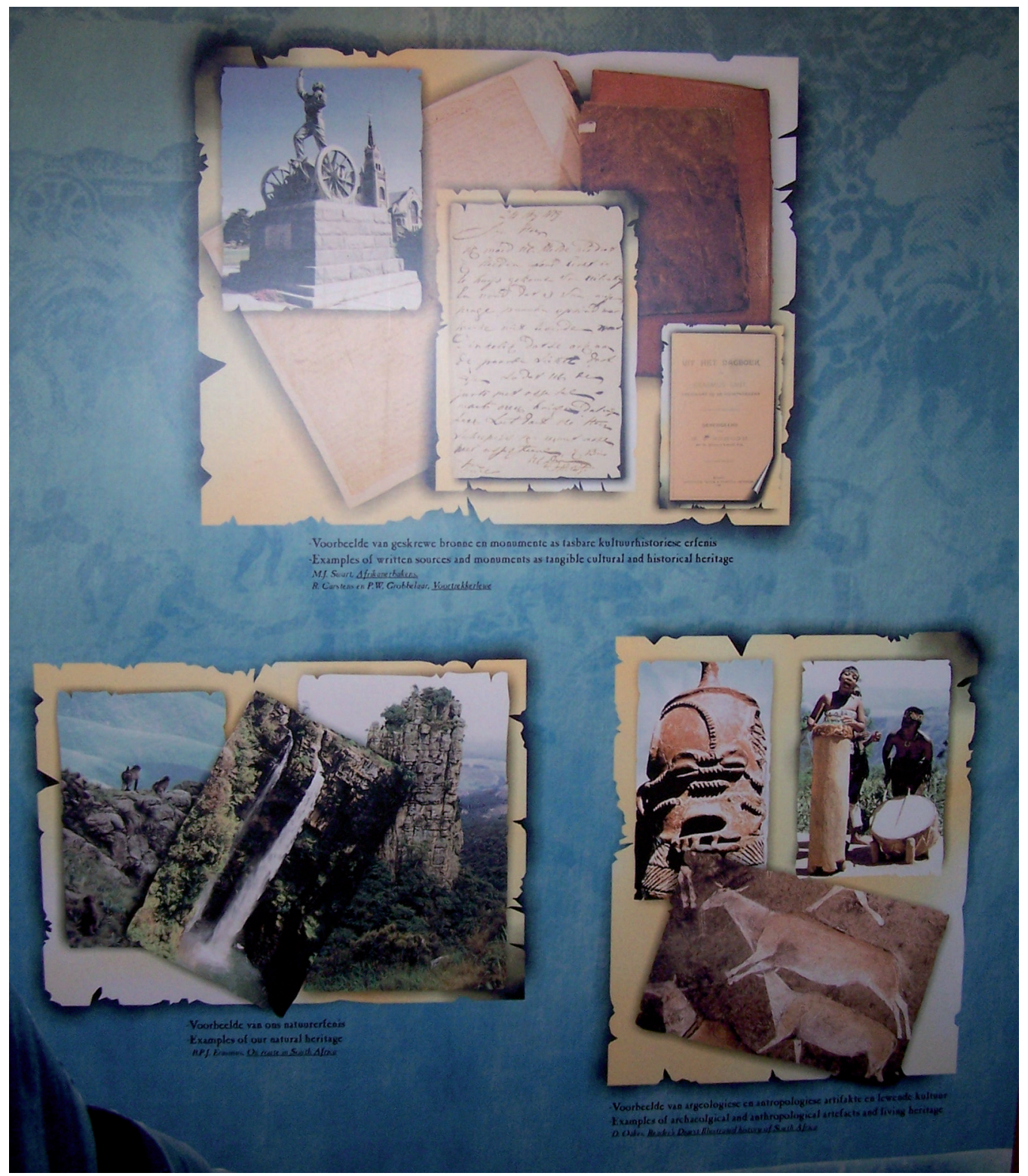

Fig. 4. Blood River Museum viser til skilnad på historie, naturarv og kulturarv, der historie kan knytast til kvite menneske og kulturarv til svarte. Foto: Line Grønstad. 
64 Kong Goodwill Zwelithini. Gjennom slektstre blir det knytt eit band mellom han og dei legendariske kongane frå tidlegare tider. Kongehuset har ei lang historie sjølv om zuluane fram til 1800-talet var ei lita gruppe. Ein stad står det på zulu: "Isilo samabandla, King Zwelithini Goodwill ka Bhekuzulu Bayethe!!!” Dette betyr: "Kongen av [zulu]nasjonen, Zwelethini Goodwill son av Kong Bhekuzulu!!!”. Sidan resten av teksten finst på engelsk og afrikaans tyder det på at denne setninga er irrelevant for andre enn dei som tilhøyrer kongeriket, altså zuluar. Teksten i panel ein seier vidare: "King Zwelithini became king of the Zulu people in 1971". Implisitt finst ideen om at det eksisterer eit slikt folk og at kongen kan ha dei som sine undersottar. Inntrykket av at utstillinga handlar om ein nasjonsbyggingsprosess blir forsterka av dette. Det er eit eksempel på at det kongelege systemet nyttar musea til å legitimere seg sjølv (Gaugue, 2001: 26; Kaplan, 1995: 39). Ingen spørsmål er stilt rundt kongehuset eller rolla det har i Sør Afrika eller i regionen.

Også Blood River Museum omtalar opphavet til zuluane, og fortel: "According to oral history the origins of the Zulu clan can be traced back to Malandela (c.1560)." Bruk av munnlege forteljingar som kjelde i utstillinga vil eg komme tilbake til. Så blir etterkommarane skildra fram til Shaka kom til makta tidleg på 1800-talet. Medan afrikandarane tidlegare i teksten blir skildra ut frå eigenskapar som gudfryktige og fridomssøkande, får vi ikkje her vite noko om korleis zuluane "er". I staden får vi høyre om handlingane som blir gjort: "Shaka's victories and subjection of surrounding clans resulted in a uniformity of language and lifestyle. Since then most black people in KwaZulu-Natal referred to themselves as "Zulu", although it is strictly speaking only the name of the royal clan." Slik blir afrikandarane sett som eit folk med dei same eigenskapane, den same religionen, det same språket og det same ønskje om fridom. Zuluane, som til liks med afrikandarane blir sett som ei folkegruppe i dag, blir i staden skildra som ei samling av mange ulike klanar. Denne måten å omtale zuluane på kan sjåast som ein reaksjon på zulunasjonalisme, ein ideologi som er tilstades også i Ncome Museum. Men samstundes er det del av nyare akademiske måtar å sjå på den historiske bakgrunnen til dei ulike folkegruppene som bur i Sør Afrika (til dømes i Carton, Laband \& Sithole, 2009).

Panel to på Ncome Museum handlar om Dingane som vart konge då broren Shaka vart drepen. Kart er nytta for å vise kor grensene gjekk for Dingane sitt rike. Ei tromme er plassert lengst til venstre i monteren. Ein merkelapp fortel at det er ei "Zulu drum", og ho ligg på ei "Food serving mat" laga av gras. Dei to gjenstandane gir inntrykk av at både kongehuset og slike gjenstandar er naturlege for zuluar. Tredje panel, "Life in KwaZulu", viser tilsynelatande meir zulukultur. At to tredjedelar handlar om kong Dingane styrkar inntrykket av at zulu som kultur og nasjon er sterkt knytt til kongehuset. Livet i det gamle Zululand blir vist som eit idyllisk tilvære, og krigar og konfliktar blant dei som i dag er zuluar blir ikkje nemnt. Heller ikkje Shaka si til tider brutale nedtrykking av andre etniske grupper i området eller den faktiske eksistensen av andre grupper i området kjem fram. Slike konfliktar er skildra andre stader av historikarar som til dømes Carolyn Hamilton og John Omer-Cooper (Hamilton, 1995; Omer-Cooper, 1995). Teksten i panel tre seier: "Before the arrival of the Voortrekkers [afrikandarane under Det store trekket], life went on as normal and the 
cultural ceremonies of the Zulu nation were observed. Poverty was rare." Problem som oppstod for zuluane kom altså ikkje før afrikandarane immigrerte. Teksten fortset. "Cultural education was based on observation and active involvement in beadwork, making of beer pots, weaving, making of assegais, cutting of shields, etc." Aktivitetane er illustrert med fotografi som viser tradisjonelt kledde zuluar, og teksten ignorerer fullstendig eksistensen av skilnadar innanfor det som i dag blir sett som zulunasjonen.

Dette perspektivet har spela ei viktig ideologisk rolle i arbeidet til historikaren Jabulani Maphalala, som deltok i arbeidet med å setje opp Ncome Museum i 1998. I si nytolking av slaget i 1998 hevdar han at "Zulu religion and culture was deeply rooted in the minds of the African people" (Maphalala, 1998: 56). Han presenterer eit essensialistisk syn på zulukultur, og identifiserer det med ein afrikansk kultur. Gjennom å ekskludere informasjon om kor dei ulike objekta i utstillinga kjem frå blir det fremja eit syn på zulukultur som einsarta og tidlaust (Girshick, 2008: 48). Dlamini kjem med ein liknande kritikk når han peikar på at mykje av perlearbeida og treskjeringane i utstillinga ikkje kjem frå det som blir rekna som kjerneområde i Zululand, men frå område lenger sør og lenger nord (2001: 134). Sjølv om utstillinga vart bytta ut i 2008 er mange av gjenstandane dei same.

Informasjonen i panelet er enkel og grunnleggande, og gir inntrykk av at utstillinga er berekna på turistar, og at informasjonen er den som blir sett som mest nøytral og viktigast. Men andre dimensjonar blir lagt til for zulutalande besøkarar. Til dømes får vi vite at "Ancestors were looked after in KwaZulu" i panel tre. Ein slik måte å formulere det på insinuerer at forfedrar, ein viktig del av tradisjo- nell religion, ikkje blir tekne vare på i dag, i motsetnad til tidlegare. Ei illustrert liste av ulike seremoniar gir lite informasjon om kva seremoniane går ut på. Zuluar kjenner sannsynlegvis att seremoniane, og på denne måten fungerer lista som bekreftande på at dei er viktige innanfor zulukulturen.

Medan utstillinga viser det tradisjonelle livet i KwaZulu som statisk, insisterer utstillinga likevel på å vere dynamisk der kongane er inkludert. Til dømes blir vi fortalt, i panel tre, at Dingane vart konge etter "his half-brother King Shaka, who was stabbed to death by Mhlangana and Mbopha kaSithayi. Prince Dingane was there but he did not stab him." Dingane vart i etterkant av slaget ved Ncome Blood River slått av broren Mpande, som vart konge etter han, og som vart forfar til dagens konge. Utstillinga framhever at det ikkje var Mpande som drap Dingane i 1840, to år etter slaget, på same vis som ho framhever at Dingane ikkje var den som sette kniven i Shaka. Medan livet gjekk som vanleg i den idylliske, statiske verda som utstillinga og panel tre teiknar frå tida før afrikandarane kom, er kongehuset alt anna enn statisk, og fylt av intriger og maktkampar.

\section{"KRIGARAR" OG "SOLDATAR"}

Tidleg på 1800-talet vidareutvikla Shaka system for militær trening og taktikk, og dette er framheva i begge musea sine utstillingar. Ncome Museum viser fram våpen, namna på regimenta som deltok under slaget, og framhevar Shaka si rolle. Det vesle av tekst bygger opp under det som finst av gjenstandar. Sjølve museet i seg sjølv er teikna som ein abstraksjon av formasjonen som zuluhæren brukte under slaget, og står vendt mot den andre sida av elva, som ein fastfrosen augneblink rett før slaget 
tok til. Blood River Museum er meir skriftleg i si framstilling. I panel fem, Military background of the Zulu, står det: "Shaka transformed the Zulu army into a formidable fighting force. All male youths, upon reaching manhood, would be incorporated into a regiment where they received training." Og vidare: "The bare-footed warriors formed a column, which was divided into regiments." Her blir zuluar kalla "warriors" eller "krigarar", men med utgangspunkt i det sterkt spesialiserte militærsystemet Shaka utvikla, hadde det ikkje vore meir naturleg å kalle dei soldatar? I neste panel, nummer seks, står det om afrikandarane, og dei er kalla "soldiers", altså "soldatar". Medan soldatar er profesjonelle kan ordet "krigar" assosierast med eigenskapar som er naturlege, som blodtørst og stoltheit. Men hæren til Shaka besto hovudsakleg av menn som hadde militærteneste med lang opplæring. Medan Blood River Museum presenterer tal, måleri, og teikningar av formasjonane til zuluane og til afrikandarane knytt til slaget, er hærformasjonen til zuluane på Ncome $\mathrm{Mu}$ seum presentert i samanheng med kong Shaka og hans betringar av hæren. Dermed blir det del av ei nasjonal forteljing heller enn ein konkret kontekst for den historiske hendinga som skjedde på staden.

\section{VOGNFØRARAR OG ANDRE SVARTE}

I panel elleve i Blood River Museum blir følgjet som gjekk med afrikandarhæren skildra som "a large number of wagon-drivers and grooms" i tillegg til "approximately $100 \mathrm{Zulu-}$ auxiliaries from Port Natal". Port Natal, no Durban, var på dette tidspunktet ikkje del av Zululand, og mange som heldt til der var flyktningar frå områda Shaka hadde lagt under seg. Panelet seier ikkje noko om desse hundre var med på å slåss. I panel seksten blir dei kalla "the Port Natal blacks". A bruke forskjellige namn kan skuldast vanskar med å handtere eksistensen av desse menneska i historia. Slik understrekar ein skilnadane heller enn likskapen mellom gruppene. Å bruke forskjellige namn på dei same menneska kan også vere med på å understreke at dei tilhøyrer "dei andre".

Også i dag er det problematisk å diskutere eksistensen av svarte og farga menneske på same side som afrikandarane under slaget. Ved inngangen til utstillinga heng ei liste over deltakande afrikandarar og britar på afrikandisk side under slaget. Det er over 460 namn. Kva med dei som blir kalla "Zulu auxilliaries", og "Port Natal blacks"? Kjenner ein ikkje til namna til nokon av desse? Cecilia Kruger seier:

The fact that there is no record of the 120 Zulu's who joined with the couple of British from Port Natal and the servants (probably all descendants of free slaves) $[\ldots]$ is a true reflection of the circumstances in the world in the mid 1800s. The names of these people were never written down (epost 12.12.2008).

Ho argumenter for at ein må forstå mangelen på kunnskap om namn ut frå tid og kontekst. Dette er eit viktig poeng. Frik Jacobs, direktøren for War Museum of the Boer Republics i Bloemfontein kjem med ei forklaring rundt denne konteksten: "Very few, if any, historians in this country, found the need or the time to write down the suffering of black people, the rural life of blacks, the disruption of their tribal traditions. It was not considered a no-no. It was considered unnecessary because they were writing to create nationalism" (i Dubin, 2006: 45). Men implisitt i Kruger sin argumentasjon er også ideen om at dei som ikkje 
hadde europeisk opphav ikkje var trekkarar. Dei var tenarar eller born av frigjorte slavar, utan namn som gir signal om kva etnisk gruppe dei høyrde til. Dei som kom frå Port Natal, derimot, kallar ho "zuluar", sjølv om dei kunne ha tilhøyrd ulike grupper på den tida. Kruger inkluderte ikkje tenarar og andre $\mathrm{i}$ lista over deltakarar under slaget basert på historisk kontekst. Kunnskap om kven dei var, vart ikkje skriven ned, men slik kontekst er ikkje nemnt i utstillinga heller. Berre to partar er skildra - afrikandarane, som hadde med nokre følgjarar, og zuluane. Utover i utstillinga er zuluane ikkje berre ei sams gruppe. Frå sirkelformasjonen der afrikandarane venta på zuluhæren denne desembermorgonen kunne "the fire power of the Voortrekkers be concentrated on the Zulu masses." Dei har blitt til ein masse.

\section{EIN ANNAN SYNSVINKEL}

Framstillinga av slaget på Blood River Museum liknar i stor grad på framstillinga i ulike bøker og anna litteratur, medan Ncome $\mathrm{Mu}$ seum har som eitt av sine føremål å komme med alternative tolkingar til den rådande forteljinga. Slaget blir berre nemnt i nokre få, korte setningar. Det er brukt meir plass på sentrale element ved hendingane før og etter slaget. Tittelen på utstillinga, "Another point of view", blir særs aktuell i panel fire, gjennom alternative forklaringar på hendingane som skjedde i 1838. Til dømes blir drapa på det afrikandiske følgjet under festen hos Dingane forklart som resultat av at handlingane til afrikandarane var ein invasjon av landet. Det femte panelet omhandlar afrikandarane sine påfølgande handlingar som hemn: "The Voortrekkers wanted to avenge the death of Retief and they armed themselves to attack the king- dom." Det sjette panelet presenterer zuluane heard that the Voortrekkers were advancing on Mgungundlovu [Dingane sin hovudstad] a decision was taken by the King in Council to stop them before they reached the Royal Palace."

I panel åtte blir avtalen som vart signert nemnt. "Many Zulu people and writers, as well as experts in the Zulu history, have emphasized that no Treaty was signed [...]." Dette har vore eit tema for diskusjon og konflikt lenge. "Afrikaans historians disagree and state that the original document was removed from the archives in Pretoria during the Anglo-Boer War [1899-1902] and then disappeared." Panelet tek ikkje berre for seg avtalen, som har vore så viktig i den juridiske grunngjevinga av eigarskap til landet etter slaget i 1838 for afrikandarane. Det tek også for seg "the Zulu meaning of reconciliation". Teksten forklarar: "The Zulu people are a proud nation who knows how to reconcile with each other or with an enemy after a confrontation. [...] It is necessary for enemies to reconcile themselves with what has taken place." Slik blir utstillinga knytt til namnet på dagen for slaget - Forsoningsdagen. Ved sidan av eit symbol for heile Sør Afrika seier teksten vidare:

The descendants of the original protagonists at the Battle of Ncome/Blood River, namely the Zulus and Afrikaner of today, are no longer enemies, by jointly participating in preserving the monuments of the sites, promoting a spirit of reconciliation and building a united South Africa.

Zuluar og afrikandarar blir presentert som separate grupper som lever saman, og på denne måten, ironisk nok, blir separat utvikling av staden for slaget gjort, som apartheid, på to forskjellige museum ved sidan av kvarandre. 
KJelder hos Blood River Museum

Medan Ncome Museum ikkje viser til kjeldene til utstillinga si, har Blood River Museum ei kjeldeliste over døra til utstillinga. Slik plasserer utstillinga seg i ein sjølvrefleksiv tradisjon karakterisert av transparens. Mykje av litteraturen er på afrikaans. Nokre typiske kjelder ser ut til å mangle. Dagleg leiar Dawie Viljoen har tidlegare omtala zuluhistorikaren Credo Mutwa for meg, men han er ikkje inkludert her. Den populærvitskaplege boka The rise and fall of the Zulu empire (1999) av forfattaren Alan Mountain er med på lista, men den anerkjende historikaren John Laband si Rope of sand. The rise and fall of the Zulu kingdom in the nineteenth century (1995), som er grundigare, og som Mountain brukar som kjelde, er ikkje med. Alle kjeldene er sekundærkjelder, og ingen primærkjelder er nemnt.

Utstillinga fortset med transparensen og sjølvrefleksiviteten i panel ein, med namnet In search for the truth. Her blir fakta knytt til slaget sett i perspektiv ved at ulike versjonar av historia blir nemnt, og ved viktigheita av å gå til primærkjeldene. "Historical events are often interpreted in different ways," står det. "The history of the Great Trek and the Trekkers in Natal [dagens KwaZulu-Natal] is by no means an exception." Cecilia Kruger fortel at dei har blitt spurt om å fjerne dette panelet sidan det tillet tvil rundt historia, og slik ho blir framstilt $\mathrm{i}$ resten av utstillinga (e-post 12.12.2008). Dei velte likevel å behalde panelet sidan slaget har så mange kjensler knytt til seg, både frå zuluar og frå afrikandarar, og det eksisterer mange myter rundt det. I følgje Kruger treng museet "[to] try and explain that there are different views and interpretations, and being a scientific institution, we must uphold this approach and acknowledge these differences." Som ein moderne museumsperson fortset ho: "No-one can really claim that their version is absolutely correct and therefore we base our display on the facts known to us. For that reason we chose NOT to remove the panel" (hennar framheving). Museet er ein vitskapleg institusjon, seier Kruger, noko som blir styrkt av at panelet hevdar å nytte "written (primary) sources" (parantes i originalsitatet). Dette står i kontrast til, ikkje sekundære kjelder, men til muntleg tradisjon: "Based on oral tradition, some historians even question the fact that the Battle of Blood River took place." Andre hevdar, i følgje panelet, at "the Voortrekkers' [afrikandarane] victory [was] a miracle”. Posisjonen til utstillinga ligg mellom desse to syna: "Somewhere between these poles, lies the truth. The search for the truth should never be complete." Dersom det er slik at vitskapleg baserte museum baserer seg på primærkjelder, slik det blir hevda her, kvifor har det seg slik at det ikkje er ei einaste primærkjelde nemnt i kjeldelista? Om dette seier Kruger.

I know that primary sources actually refer to dairies, newspapers, primary accounts etc. In other words it is not quite primary sources used in the research for the display, but sources all based on primary sources. This term was used to differentiate between these sources and oral accounts (epost 12.12.2008).

Skriftlege kjelder er ikkje det same som primærkjelder, noko ho anerkjenner i e-posten, men den viktige skilnaden her er mellom skriftleg og munnleg, der den skriftlege er sett som viktigast. Dette kan sjåast som problematisk når slaget det er snakk om hende på ei tid der zuluar i liten eller ingen grad kunne skrive, og verken zulu eller afrikaans fanst som skrift- 
språk. Då utelet synet på kva som er gode kjelder svært mange stemmer. Det er også problematisk fordi verken munnlege eller skriftlege tradisjonar er nøytrale eller uskuldige (Golan, 1994: 9).

Panelet har tre illustrasjonar som understrekar poenga i teksten. Det fyrste viser eit monument, nokre gulna dokument som tydelegvis er gamle, og ei gammal dagbok. Under står det at desse er "examples of written sources and monuments as tangible cultural and historical heritage". Illustrasjon nummer to viser fotografi av ein foss, apekattar og nokre særprega steinformasjonar. Her er underteksten "natural heritage". Den tredje illustrasjonen inkluderer fotografiar av holemaleri, ei leirmaske og nokre unge, svarte kvinner som speler på tradisjonelle trommer. Teksten under viser til dette som "examples of archaeological and anthropological artefacts and living heritage". Slik har utstillinga kategorisert verkelegheita $\mathrm{i}$ tre forskjellige grupper. "Historie" er ei gruppe, "natur" er ei, og "levande kulturarv" er den tredje gruppa. Slik blir historiske gjenstandar sett inn i ein samanheng assosiert med kvite menneske, og svarte menneske som driv med "levande kulturarv" blir slått saman med arkeologiske gjenstandar. Kvit kultur blir her sett som noko dynamisk, noko med utvikling, ei fortid, primærkjelder i form av brev og dagbøker, og fysiske gjenstandar i form av monument og historiske museum. Og er det nødvendigvis ein samanheng mellom holemaleri og dagens trommespeling blant svarte? Har det ikkje skjedd endringar historisk blant bebuarane i regionen før europearane kom? Dei mange holemaleria er til dømes hovudsakleg gjort av khoisanfolk, som vart utrydda av zuluar, afrikandarar og andre før byrjinga av 1900-talet. Likevel gir tredelinga i illustrasjo- nane inntrykk av at den levande kulturarven representert med dei trommande kvinnene har eksistert som eit statisk fenomen sidan førhistorisk tid, og er uendra heilt til våre dagar. Slik skil framstillinga seg frå Ncome Museum gjennom at det der blir vist til eit brot $\mathrm{i}$ den statiske, einsarta kulturarven fyrst då afrikandarane kom til regionen.

\section{DISKUSJON}

$\AA$ kunne setje opp eit museum som fortel alternative versjonar av den rådande forteljinga om slaget ved Ncome Blood River, vart mogleg gjennom dei mange endringane som har funne stad i museumssektoren i Sør Afrika sidan 1980-talet. Inkluderinga av grupper tidlegare sett vekk frå blir gjort, og nye føremål for musea blir søkt.

Tradisjonelt har kvit historie blitt presentert kronologisk, og svart historie som statiske sosiale og kulturelle formar. Ein kan også seie at kvit historie blir formidla som makrohistorie, og svart som mikrohistorie (Coombes, 2004: 179). Det same er tilfellet ved Blood River Museum og Ncome Museum. Fyrstnemnte presenterer ein kronologisk gjennomgang av militære og politiske hendingar, den andre presenterer statisk kultur med fokus på kvardagsliv. Det er likevel unnatak, nemleg Ncome Museum sin presentasjon av kongefamilien. Det same mønsteret kan sjåast $\mathrm{i}$ andre museum i regionen, med kvit historie og zulukongehuset som dynamisk makrohistorie, og zulukultur som statisk (Wright \& Mazel, 1991).

Utstillingar kan brukast til å komme med alternative forteljingar (Buntinx \& Karp, 2006: 207). Begge musea argumenterer for at dette gjeld dei. På Ncome ligg dette i botn sidan utstillinga har fătt namnet "Ncome: 
Another point of view". Utstillinga endar i panel atten, som informerer om prosessen rundt oppføringa av museet. Det var eitt av fleire prosjekt som hadde som føremål "to address the imbalances in the heritage landscape". Med det som grunnlag var intensjonen å komme med ei positiv nytolking av slaget og konfliktane på 1830-talet mellom afrikandarar og zuluar, sett frå zuluane si side. Cecilia Kruger seier seg samd i behovet for å komme med alternative versjonar av slaget grunna $i$ den einsidige historieskrivinga under apartheidstyret. Men ho argumenterar for at "some interpretations of these events became absurd and farfetched" (epost 12.12.2008). Dette leidde til avgjersla om å etablere ei ny utstilling i 2002 ved Blood River Museum, etter at Ncome Museum var etablert. Målet var å komme med ein objektiv versjon. Utstillinga blir også kalla "fairly balanced" (Mills \& Williams, 2006: 37) og kjem med "an objective account” (Coan, 22.07.2003) av forteljinga rundt slaget. Utstillinga vart sett opp for å styrke ein diskurs rundt slaget som reaksjon på andre diskursar. Ut frå analysane i denne artikkelen vil eg likevel argumentere for at den objektive framstillinga sviktar, og glimt av kontroversar og vanskar med namn og omgrep viser at det ikkje er ei nøytral framstilling.

Sinothi Thabethe som tidlegare var leiar for Ncome Museum, argumenterer i ein artikkel at dei fleste museum let vere å ta opp kontroversar i historia: "Each museum tends to articulate and present a certain ideology by presenting one side of the story without any acknowledgement of the other" (2008: 5). Det kan i artikkelen synast som at Thabethe peikar på mangelen av eit zuluperspektiv ved Blood River Museum, men det same kan seiast om Ncome Museum, der afrikandiske, sotho, khoisan eller andre perspektiv manglar. Dette spør eg Mkhulisi, leiaren for Ncome Museum, om. Mkhulisi svarer:

Some people have been critical, saying 'now, are you not doing what they did? It is more like you are now coming with your Zulu perspective [alone]. Are you not promoting the spirit of reconciliation?' The museums are part of the national agenda of the government of reconciling these people, and slowly we are working well with [Blood River Museum]. The politics of South Africa do come in even in the museums, but slowly that will start to evaporate. It is true that there were two sides, and these two sides are giving, let me not say two different accounts, more like different accounts. [...] So we hope we are also playing a role in trying to paint a picture of what happened here in 1838, but more giving that Zulu voice as well, that we think was lacking (intervju 24.10.2008: 2).

Mkhulisi ser hendingane i 1838 som viktige for å forstå kvifor landet er som det er i dag. På liknande vis argumenterer arrangørane av markeringa av årsdagen på slaget på Blood River Museum: "As the history of the Great Trek is no longer taught in any government schools, an entire generation is oblivious of their history." Gjennom å markere hendingar som dette ønskjer gruppa å gjere barn og vaksne merksame på eiga historie (vidareformidla i epost frå Kruger, 12.12.2008). Føremåla med å minnast historia er likevel forskjellige. Medan Mkhulisi argumenterer for endring av samfunnet med utgangspunkt i slik minning, argumenterar arrangørane for å preservere historia for afrikandarar, dei ho angår, altså dei afrikandiske etterkommarane. Som ein kontrast til begge desse posisjonane kan det argumenterast for at bruken av slaget og forteljinga er viktigare enn dei faktiske hendingane rundt 
slaget. Valet om å formidle endring eller preservering har effekt på korleis historia blir brukt i dag, og måten landet fungerer.

Det kan synast som at det vil ta si tid før musea kan slåast saman til eitt. Eg spør leiarane på musea og Cecilia Kruger om kva dei trur om eitt museum i staden for to. Mkhulisi svarer: "Yes, there is a lot that we can talk about on this subject of reconciliation. But we hope, slowly, slowly [it will happen], because the younger generations are starting to go to the same schools, whites and blacks" (intervju 24.10.2008: 3). Medan Mkhulisi er framtidsretta, grunnar Kruger situasjonen med to museum i situasjonen landet er i. "What you see on this battlefield and the interpretation thereof, is unfortunately symptomatic of the situation in South Africa - people still see their own histories and heritage as being exclusive, and their interpretations of events as being the only correct interpretations" (epost 12.12.2008). Viljoen trur at eitt museum i staden for to ville ført til ei betring i den økonomiske situasjonen til museet. Medan Ncome Museum er statleg finansiert er Blood River Museum privat og får ikkje direkte statleg støtte. Slik kan kritikken av Ncome Museum si framstilling av hendingane, slik til dømes omvisaren min i 2004 kom med, indirekte sjåast som kritikk av post1994-regimet. Men Viljoen ser også fordelar med å vere to museum: "Because on this side we can concentrate on the Voortrekker side, and on the other side they concentrate on the Zulu side of the history so that makes it a bit easier for us and them." Han ser såleis vekk frå konteksten til afrikandarane sine handlingar, og konsentrerer seg om eit utval av hendingane. Viljoen fokuserer på afrikandarane, og deira eksklusive rett til forteljinga. Deira "great-great grand parents made the vow to God and the Zulus were not involved in that" (intervju 24.10.2008: 6-7). Slik har darane gav til Gud blitt styrka på eit tidspunkt i Sør Afrika der etnisitet og hudfarge ikkje lenger er legitime årsaker til ekskludering.

\section{KONKLUSJON}

Musea er del av diskursar som forklarer slaget på ulike måtar, og er sjølve med på å forme desse forklaringane og meiningane. Tradisjonelt har forteljingar om slaget ved Ncome Blood River framheva positive sider ved afrikandarane si oppleving. Slike forteljingar har etterkvart oppnådd ein hegemonisk posisjon $\mathrm{i}$ store delar av Sør Afrika, og Blood River Museum tek dels del i ein slik hegemonisk tradisjon. Ncome Museum vart sett opp som ein reaksjon på denne hegemoniske tradisjonen, og framhevar i staden zulukulturen sin plass i denne delen av Sør Afrika. I den hegemoniske diskursen vert slaget sett som eit teikn frå Gud om at afrikandarane tilhøyrde dette landet, og hadde rett til å vere her. Slaget var lenge viktig for afrikandarane, men vart etter kvart også viktig for zuluar og andre 'svarte' sørafrikanarar. For eksempel såg ANC på slaget som bevis på at dei kunne bruke våpen og fysisk makt i kampen for rettferd og demokrati.

Dei to museumsutstillingane ber preg av ei dikotomisering der dei to etniske gruppene speglar seg i kvarandre. Andre etniske grupper vart sett som irrelevante begge stader. Dette var særleg tydeleg i Blood River si utstilling, der 'svarte' og andre som var saman med afrikandarane ofte er namnlause og utan identitet eller der same gruppe blir gitt forskjellige namn. Det var også tydeleg i Ncome si utstilling, der konfliktar mellom dei som heldt til i området og som i dag blir sett som zuluar, er tona ned eller sett vekk frå, og kongehuset 
72 framheva. Den tydelege dikotomiseringa i det sørafrikanske samfunnet gjorde det mogleg å utvikle separate framstillingar av slaget, og fylle det med ulike meiningar. Diskursane forma gjennom desse prosessane har gjort inkluderinga av andre meiningar vanskelege sidan separasjon mellom gruppene er eit av premissa som ligg til grunn for framstillingane. Dikotomisering og ekskludering har såleis ein klarare plass $\mathrm{i}$ utstillingane ved dei to musea enn bodskapen om forsoning.

\section{BIBLIOGRAFI}

Blaser, T. (2004). A New South African Imaginary: Nation Building and Afrikaners in Post-Apartheid South Africa. South African Historical Journal, 51, 179-198.

Bredekamp, J. (13.10.2006). The question of the emancipation of the Slaves and the Great Trek: In retrospect. Paper presentert på Battle of Blood River/Ncome and its Legacy: Different Perspectives. Symposium arranger av Voortrekker Monument, Pretoria.

Buntinx, G., \& Karp, I. (2006). Tactical Museologies. I I. Karp, C. A. Kratz, L. Szwaya \& T. YbarraFrausto (red.), Museum Frictions. Public Cultures/Global Transformation. Durham and London: Duke University Press.

Carton, B., Laband, J. \& Sithole, J. (2009), Zulu Identities. Being Zulu, Past and Present. Pietermaritzburg: University of KwaZulu-Natal University Press.

Coan, S. (22.07.2003). A Tale of Two Museums. The Natal Witness (Daily newspaper for KwaZulu-Natal).

Coetzee, C. (1998). Krotoä remembered: a mother of unity, a mother of sorrows. I S. Nuttal \& C. Coetzee (red.), Negotiating the past: The making of memory in South Africa. Cape Town: Oxford University Press.
Coombes, A. E. (2004). Visual Culture and Public Memory in a Democratic South Africa. Johannesburg: Wits University Press.

Dlamini, N. (2001). The Battle of Ncome project: state memorialism, discomforting spaces. Southern African Humanities, 13 (December 2001), 125-138.

du Toit, A. (1980). On interpreting the History of Afrikaner political thinking - some problems and issues. I A. König \& H. Keane (Eds.), The meaning of history. Problems in the interpretation of History with possible reference to examples from South African History such as the Battle of Blood River(pp. 114-139). Pretoria: University of South Africa.

du Toit, A., \& Giliomee, H. (1983). Afrikaner political thought: Analysis \& Documents. Volume One. 1780-1850 (Vol. One). Cape Town \& Johannesburg: David Philip.

Dubin, S. C. (2006). Transforming Museums. Mounting Queen Victoria in a Democratic South Africa. New York: Palgrave MacMillan.

Ehlers, A. (2003). Apartheid Mythology and Symbolism. Desegregated and Re-invented in the Service of Nationbuilding in the New South Africa: The Covenant and the Battle of Blood/Ncome River. Paper presentert på konferansen 'Founding Myths of the New South Africa' arranger av GRAS (Research Group on South Africa) ved University of Reunion 29-31.03.2003, http://academic.sun.ac.za/history/downloads/ehlers/apartheid_myth_symbolism.pdf. Stellenbosch: Department of History at the University of Stellenbosch.

Gaugue, A. (2001). Myths, Censorship and the Representation of Precolonial History in the $\mathrm{Mu}-$ seums of Tropical Africa. Museum International, 53(3), 26-31.

Giliomee, H. (2003). The Afrikaners. Biography of a people. Cape Town: Tafelberg.

Gilje, N. (2007). Apartheidideologi og materiell kul- 
tur - en analyse av Voortrekkermonumentet i Pretoria. Tidsskrift for kulturforskning, 6(1-2), 5-25.

Girshick, P. (2008). Ncome/Bloed Rivier/Blood River: Nation building and Ethnic Nationalism in Post-Apartheid South Africa. Msunduzi Journal, 1, 38-54.

Golan, D. (1994). Inventing Shaka. Using History in the Construction of Zulu Nationalism. Boulder \& London: Lynne Rienner Publishers.

Guy, J. (1998). Reinterpretations of Zulu perceptions of the Boer/Zulu conflict in the 1830s. Paper presentert på Reinterpretation of the Battle of Ncome/Blood River. Eindagsseminar arrangert 31 oktober 1998, University of Zululand.

Hamilton, C. (1995). Introduction. I C. Hamilton (Ed.), The Mfecane Aftermath. Reconstructive Debates in Southern African History (pp. 1-9). Johannesburg \& Pietermaritzburg: Witwatersrand University Press \& University of Natal Press.

Jørgensen, M.W., \& Phillips, L. (1999). Diskursanalyse som teori og metode. Frederiksberg: Roskilde Universitetsforlag.

Laband, J. (1995). Rope of Sand. The Rise and Fall of the Zulu kingdom in the Nineteenth Century. Johannesburg: Jonathan Ball Publishers.

Laband, J. (2009). 'Bloodstained Grandeur'. Colonial and Imperial Stereotypes of Zulu Warriors and Zulu Warfare. I B. Carton, J. Laband \& J. Sithole (red.), Zulu identities. Being Zulu, Past and Present. Pietermaritzburg: University of KwaZuluNatal Press.

Maphalala, J. S. M. (1998). The Re-interpretation of the War of Ncome, 16. December 1838. Paper presentert pa Reinterpretation of the Battle of Ncome/Blood River. Eindagsseminar arrangert 31 October 1998, University of Zululand.

Mills, G., \& Williams, D. (2006). 7 Battles that Shaped South Africa. Cape Town: Tafelberg Publishers.

Mountain, A. (1999). The Rise and Fall of the Zulu Empire. Constantia: kwaNtaba Publications.
Omer-Cooper, J. (1995). The Mfecane Survives its Critics. I C. Hamilton (Ed.), The Mfecane Aftermath. Reconstructive Debates in Southern African History (pp. 277-298). Johannesburg \& Pietermaritzburg: Witwatersrand University Press \& University of Natal Press.

Sithole, J. (2009). Preface. Zuluness in South Africa: From 'Struggle' Debate to Democratic Transformation. I B. Carton, J. Laband \& J. Sithole (red.), Zulu Identities. Being Zulu, Past and Present. Pietermaritzburg: University of KwaZuluNatal Press.

Thabethe, S. (2008). Presentation of Historical Controversies in Exhibitions. Msunduzi Journal, 1, 510.

van Jaarsveld, A. (2008). Meaning of the work of historians in the perception of the battle at Bloed Rivier Ncome. Tale heldt pa Commemoration of the Battle of Bloedrivier Ncome 16.12.2008, Ncome Museum.

Visser, W. (2004a). Coming to terms with the past and the present: Afrikaner experience of and reaction to the "new" South Africa. Førelesing heldt ved Centre of African Studies ved København Universitet 30.09.2004, http://academic.sun.ac.za/history/downloads/visser/coming_to_terms_with_past_present.pdf. Stellenbosch: Department of History at the University of Stellenbosch

Wright, J., \& Mazel, A. (1991). Controlling the Past in the Museums of Natal and KwaZulu. Critical Arts, 5(3), 59-77.

\section{ANDRE KJELDER}

Kruger, Cecilia, konservator ved Voortrekker Monument, epost motteke 12.12.2008

Mkhulisi, Nhlanhla, museumsleiar for Ncome Museum, intervju 24.10.2008

Viljoen, Dawie, museumsleiar for Blood River Museum, intervju 24.10.2008 
LINE GRøNSTAD

$74 \quad{ }^{*}$ Line Grønstad. Mastergrad $i$ kulturvitskap fra Universitetet i Bergen og Master of business administration (MBA) frä Høgskulen i Bodø. Har arbeidd som kulturforskar hos Agderforskning, og er no ved Norsk etnologisk gransking ved Norsk Folkemuseum.

Address: Agderforskning

Gimlemoen 19,

N-4630 Kristiansand

E-mail: linegronstad@gmail.com 